\title{
Toxicity of High-Dose Chlorambucil in Wistar Rats
}

\section{J. TOMENENDÁLOVÁ ${ }^{1}$, J. MAYER ${ }^{2}$, M. DOUBEK ${ }^{2}$, P. SCHEER ${ }^{1}$, D. HORKÝ ${ }^{4}$, K. ŘEHÁKOVÁ ${ }^{3}$, J. DOUBEK ${ }^{1}$}
${ }^{1}$ Department of Physiology, Faculty of Veterinary Medicine, University of Veterinary and Pharmaceutical Sciences, Brno, Czech Republic
${ }^{2}$ Department of Internal Medicine Hematoncology, Faculty Hospital Brno, Czech Republic
${ }^{3}$ Central Clinical Laboratory, Faculty of Veterinary Medicine, University of Veterinary and Pharmaceutical Sciences, Brno, Czech Republic
${ }^{4}$ Department of Histology and Embryology, Masaryk University, Brno, Czech Republic

Received October 12, 2007

Accepted June 11, 2008

\begin{abstract}
Tomenendálová J., J. Mayer, M. Doubek, P. Scheer, D. Horký, K. Řeháková, J. Doubek: Toxicity of High-Dose Chlorambucil in Wistar Rats. Acta Vet. Brno 2008, 77: 595-602.

The aim of this study was to determine the maximum tolerated dose and the haematological and non-haematological toxicity of chlorambucil in male Wistar rats. Chlorambucil (pulverized pills or pure substance) was dissolved in ethanol and administered orally at a dose ranging from 0.15 to $50 \mathrm{mg} / \mathrm{kg} /$ day for 5 days.

Evaluations of experimental rats included general clinical state of health, body weight, haematological indicators (red blood cell count, white blood cell count, platelet count, differential leukocyte count, packed cell volume and haemoglobin concentration), biochemical plasma indicators (urea, creatinine, ALP, ALT, AST, Na, K, Cl), immunophenotype of leukocytes (CD3, CD8 and CD4 markers), as well as histopathology.

Doses of chlorambucil from 0.15 to $0.75 \mathrm{mg} / \mathrm{kg} /$ day had no effect on the general clinical state of health as well as on other laboratory variables. Doses of $2-12 \mathrm{mg} / \mathrm{kg} / \mathrm{day}$ were well tolerated, but mild myelotoxicity (leukopaenia) and elevated activities of liver transaminases were found. Doses of 20 to $50 \mathrm{mg} / \mathrm{kg} /$ day were myelotoxic $(p<0.01)$ with prevailing lymphopaenia but only minimum effects on red blood cells and platelets. Histology revealed pneumotoxicity, nephrotoxicity and damage to the gastrointestinal tract. Doses of 40 and $50 \mathrm{mg} / \mathrm{kg} /$ day resulted in acute lethal effects in $50 \%$ and $75 \%$ of individuals, respectively.

Results of this study are intended for use in the testing of chlorambucil in combination with other drugs as a conditioning for bone marrow transplantation.
\end{abstract}

Haematological toxicity, non-haematological toxicity, acute lethal effect, Leukeran, blood cells, anti-cancer therapy

Chlorambucil - 4-\{4-[bis(2-chlorethyl)amino]phenyl $\}$ butyric acid (Czech Pharmacopeia, 1997) and its metabolites are alkylating agents - substances able to form covalent bonds with proteins and DNA. Structural and functional damage to DNA leads to cytotoxic, mutagenic and cancerigenic effects (Calabresi et al. 1993). Cells affected by tumorous transformation are more susceptible to the effects of alkylating substances than the healthy ones. This fact is being employed in the therapy of oncologic diseases. Chlorambucil was developed in $1950 \mathrm{~s}$ as a nitrogenous derivative of yperite. At present, it is used for the therapy of chronic lymphatic leukaemia, in particular, low-grade non-Hodgkin's lymphoma and Hodgkin's disease (Pangalis et al. 2002; Nicolle et al. 2004). Chlorambucil is the first-choice drug that may be combined with other chemotherapeutics or steroids. There are many therapeutic regimens with variable dosing. Standard low-dose regimen is $0.1-0.2 \mathrm{mg} / \mathrm{kg} /$ day in human medicine. Chlorambucil is used also in veterinary medicine in the treatment of canine and feline lymphoma usually in combination with the other drugs (prednisone, vincristin). Doses and exposure time vary in consideration of the regimen $(0.1-0.4 \mathrm{mg} / \mathrm{kg} /$ day) (Boyce and Kitchell 2000; Kiselow et al. 2008). Due to its relatively low toxicity, 
possibility of oral administration and low cost, it is an attractive drug used in the combined treatment of haematological malignancies that are otherwise difficult to handle.

This study was aimed at determining the maximum tolerated dose and the haematological and non-haematological toxicity of chlorambucil in Wistar rats. Results of this study are intended for use in the testing of combinations of chlorambucil with other chemotherapeutics (especially fludarabine). This combination will be tested as preparing non-myeloablative regimen for bone marrow transplantation, as we hypothesized that this chlorambucilfludarabine combination might have the potential as a good conditioning for high-risk lymphoid malignancies.

\section{Materials and Methods}

The experiment was divided into three stages: stage 1 , determination of the toxicity of doses of $0.15,0.25$, 0.5 , and $0.75 \mathrm{mg} / \mathrm{kg} /$ day; stage 2 , determination of the toxicity of doses of $2,4,8$, and $12 \mathrm{mg} / \mathrm{kg} / \mathrm{day}$; and stage 3 , determination of the toxicity of doses of $20,30,40$, and $50 \mathrm{mg} / \mathrm{kg} / \mathrm{day}$. The drugs were administered for five consecutive days after 14-day acclimatization. Clinical examination was performed daily, haematological examination in the $1^{\text {st }}, 2^{\text {nd }}$ and $4^{\text {th }}$ week and biochemical examination in the $1^{\text {st }}$ and $3^{\text {rd }}$ week after the therapy had finished. Animals of stage 3 were also sampled two months after therapy had finished. Animals of stages 1 and 2 were euthanized one month and animals of stage 3 two months after cessation of therapy, and the samples for histopathological examination were collected.

The experiment was approved by the Ethics Committee of the University of Veterinary and Pharmaceutical Sciences Brno, Czech Republic.

Animals

All experiments were performed using SPF outbred Wistar rats (males) ranging in body weight from 195 to $200 \mathrm{~g}$, purchased from Anlab (Prague, Czech Republic). Acclimatisation lasted 2 weeks. Animals had free access to drinking water and complete food (Biostan Mypo, Biosta, Blučina, Czech Republic) supplied ad libitum during the whole experiment. Fifty-two animals were randomly divided into 12 experimental and 1 control groups. Each group included 4 animals and was used to test one of the drug concentrations; the control group included 4 animals, as well. The rats were examined clinically after acclimatisation; they were blood sampled through venous approach to determine initial haematological and biochemical values as well as immunophenotypes of leukocytes.

Drugs

Stage 1: Tablets of Leukeran tbl obd. $2 \mathrm{mg}$ (GlaxoWellcome, Great Britain) were pulverized, then dissolved in $60 \%$ ethanol and the solution of each concentration $(0.15,0.25,0.5,0.75 \mathrm{mg} / \mathrm{kg} /$ day $)$ was administered using a gastric tube.

Stage 2 and 3: Chlorambucil (LKT Laboratories, Minnesota, USA) was dissolved in 96\% ethanol, divided in aliquots in micro test tubes and kept at $-20{ }^{\circ} \mathrm{C}$ until use. Shortly before use, the solution was diluted by water for injection down to the ethanol concentration of 50 to $60 \%$ and administered at the right concentration (2-12 $\mathrm{mg} / \mathrm{kg}$ /day and 20-50 mg/kg day, respectively) by a gastric tube to rats anaesthetized for a short period by ether. Chlorambucil was administered once daily for 5 consecutive days in all the experimental stages.

Ethanol $(60 \%, 0.7 \mathrm{ml}$ per animal) was administered orally to control animals once daily for 5 consecutive days.

We started with low doses of chlorambucil corresponding to therapeutic doses used for the treatment of human lymphoid malignancies $(0.1-0.2 \mathrm{mg} / \mathrm{kg} / \mathrm{day})$. Then we proceeded to higher concentrations of chlorambucil to achieve toxicity.

Sample collection, examination

Blood was collected from v. caudalis lateralis under mild ether general anaesthesia. Rats were examined clinically on a daily basis; body weight was measured twice a week during the first 14 days and only once per week later, for one (stage 1 and 2) or two months (stage 3) from the start of the experiment. Haematological indicators such as the red blood cell count, white blood cell count, platelet count, differential leukocyte count, packed cell volume, and haemoglobin concentration were determined using the analyzer Celltac alpha MEK 6318, Nihon Kohden, Japan. To evaluate differential leukocyte count, blood smears were stained according to Pappenheim. These examinations were performed before the experiment (initial values) and in $1^{\text {st }}, 2^{\text {nd }}$ and $4^{\text {th }}$ week after the therapy had finished. Six survived animals in stage 3 (three after the dose $20 \mathrm{mg} / \mathrm{kg}$, two after the dose $30 \mathrm{mg} / \mathrm{kg}$ and one after the dose $40 \mathrm{mg} / \mathrm{kg}$ ) were also sampled two months after treatment. Biochemical examination included following indicators: urea, creatinine, ALP, ALT, AST, Na, K, and Cl determined using an automatic analyzer Konelab 20i (Thermo Scientific, Finland). Biochemical variables were analyzed before (initial values) and in $1^{\text {st }}$ and $3^{\text {rd }}$ week after therapy. Flow-cytometric examination aimed at CD3, CD4 and CD8 markers (Cytomics FC 500, Beckman Coulter Inc., FL, USA) was preformed before the therapy and 3 days after the therapy had finished. Samples collected for histopathology included heart, lungs, adrenals, liver, spleen, 
oesophagus, stomach, duodenum, ileum, caecum, colon descendens, urinary bladder, and brain from individuals that died or were euthanized using ether. Histological specimens were stained by hematoxylin-eosin and Azan and examined under light microscopy.

\section{Statistical evaluation}

We determined the arithmetic mean and standard deviation. Paired Student's $t$-test was used for the evaluation of significance of differences between pre-treatment and post-treatment values (significant $p<0.05$, highly significant $p<0.01$ ). The evaluation was performed using Microsoft Excel software.

\section{Results}

\section{Clinical changes}

No overt changes of the clinical state of health were noticed in stage 1 and 2.

Stage 3: Three and two individuals died before the end of the experiment in the group of rats given $50 \mathrm{mg} / \mathrm{kg}$ and $40 \mathrm{mg} / \mathrm{kg}$ of chlorambucil, respectively. All groups showed body weight loss and growth retardation, apathy, decreased food intake and moderate diarrhoea.

Control group: No overt changes of the clinical state of health were noticed in 3 of 4 animals. One rat was euthanized due to aspiratory pneumonia.

\section{Haematology}

The severity of myelotoxicity of chlorambucil depends on the dose; leukocytes were the cells of predominant damage. Low doses of chlorambucil (stage $1-0.15,0.25$, $0.5,0.75 \mathrm{mg} / \mathrm{kg} /$ day) caused only minor decrease of leukocyte counts, while medium doses $(2,4,8,12 \mathrm{mg} / \mathrm{kg}$ /day) resulted in more marked leukopaenia. High doses $(20,30$, $40 \mathrm{mg} / \mathrm{kg}$ ) of chlorambucil lead to considerable leukopaenia together with dominant lymphopaenia (Table 1, 2). The highest dose $(50 \mathrm{mg} / \mathrm{kg})$ resulted in the death of 3 of 4 rats and leukopaenia in one survivor (data were not statistically processable). The leukocyte population in rats treated with high doses was within the reference range two months after the therapy (56 days) but lower than before chlorambucil administration. There were only minimal effects on populations of red blood cells and platelets in all stages of the experiment.

A mild increase of total leukocytes was noticed in the control group $(p<0.05)$ neutrophilia and lymphocytosis occurred.

Table 1. Total leukocyte count G/1. All experimental stages

\begin{tabular}{|c|c|c|c|c|}
\hline \multirow{2}{*}{$\begin{array}{c}\text { Chlorambucil dose } \\
\mathrm{mg} / \mathrm{kg} / \mathrm{day}\end{array}$} & \multirow{2}{*}{ Initial values } & & \multicolumn{3}{|c|}{ Days after the end of therapy } \\
\cline { 3 - 5 } & & $2-8$ & $10-16$ & $22-27$ \\
\hline 0.15 & $11.00 \pm 2.78$ & $9.68 \pm 3.29$ & $13.53 \pm 1.03$ & $\#$ \\
\hline 0.25 & $12.03 \pm 1.51$ & $9.28 \pm 1.58$ & $15.65 \pm 3.91$ & $\#$ \\
\hline 0.5 & $12.35 \pm 2.22$ & $10.10 \pm 1.04$ & $14.00 \pm 3.83$ & $\#$ \\
\hline 0.75 & $11.25 \pm 4.75$ & $9.75 \pm 0.86$ & $11.53 \pm 2.64$ & $9.10 \pm 3.21$ \\
\hline 2 & $12.18 \pm 1.02$ & $6.70 \pm 1.80^{*}$ & $8.15 \pm 1.97$ & $8.72 \pm 0.87$ \\
\hline 4 & $10.35 \pm 1.53$ & $6.05 \pm 0.71^{*}$ & $8.28 \pm 2.94$ & $7.65 \pm 1.91$ \\
\hline 8 & $9.40 \pm 1.35$ & $6.05 \pm 0.70^{*}$ & $6.30 \pm 1.24$ & $7.43 \pm 2.08$ \\
\hline 12 & $11.25 \pm 0.94$ & $6.17 \pm 3.03^{*}$ & $6.05 \pm 0.86$ & $8.00 \pm 4.46$ \\
\hline 20 & $11.63 \pm 1.97$ & $0.90 \pm 0.41^{* *}$ & $5.73 \pm 2.40$ & $9.20 \pm 0.00$ \\
\hline 30 & $11.68 \pm 2.21$ & $0.63 \pm 0.25^{* *}$ & $6.73 \pm 2.44$ & $\#$ \\
\hline 40 & $10.30 \pm 0.58$ & $0.33 \pm 0.06^{* *}$ & $8.10 \pm 0.00$ & $13.00 \pm 2.14$ \\
\hline 50 & $9.82 \pm 2.61$ & $1.30 \pm 0.00^{\mathrm{a}}$ & & $\#$ \\
\hline Control & $8.00 \pm 2.77$ & $14.47 \pm 3.93^{\mathrm{b}}$ & $13.13 \pm 2.35$ & $\#$ \\
\hline
\end{tabular}

\# Value was not assessed

* Significant decrease $(p<0.05)$

** Highly significant decrease $(p<0.01)$

a Without statistical evaluation due to low number of animals

b Significant increase $(p<0.05)$ 
Table 2. Differential leukocyte count. Stage 3

\begin{tabular}{|c|c|c|c|c|c|c|c|}
\hline \multirow{2}{*}{$\begin{array}{l}\text { Days after the } \\
\text { end of therapy }\end{array}$} & \multicolumn{2}{|c|}{ Indicator } & \multicolumn{5}{|c|}{ Chlorambucil dose $\mathrm{mg} / \mathrm{kg} /$ day } \\
\hline & & & 20 & 30 & 40 & 50 & Control \\
\hline \multirow{10}{*}{ Initial values } & \multirow[t]{2}{*}{ Ly } & $\mathrm{G} / 1$ & $9.28 \pm 2.13$ & $9.30 \pm 2.19$ & $8.56 \pm 0.67$ & $8.15 \pm 2.47$ & $7.28 \pm 2.38$ \\
\hline & & $\%$ & $79.3 \pm 5.3$ & $80.7 \pm 2.5$ & $83.3 \pm 7.2$ & $84.5 \pm 2.3$ & $91.3 \pm 2.0$ \\
\hline & \multirow[t]{2}{*}{ Mo } & $\mathrm{G} / \mathrm{l}$ & $0.94 \pm 0.21$ & $1.42 \pm 0.52$ & $0.99 \pm 0.54$ & $0.86 \pm 0.52$ & $0.03 \pm 0.04$ \\
\hline & & $\%$ & $8.1 \pm 1.3$ & $13.2 \pm 6.3$ & $9.5 \pm 4.8$ & $8.5 \pm 2.8$ & $0.4 \pm 0.6$ \\
\hline & \multirow[t]{2}{*}{$\mathrm{Neu}$} & $\mathrm{G} / \mathrm{l}$ & $1.36 \pm 0.29$ & $0.76 \pm 0.80$ & $0.74 \pm 0.29$ & $0.65 \pm 0.38$ & $0.63 \pm 0.43$ \\
\hline & & $\%$ & $12.3 \pm 4.4$ & $5.8 \pm 4.9$ & $7.1 \pm 2.5$ & $6.5 \pm 3.5$ & $7.0 \pm 2.0$ \\
\hline & \multirow[t]{2}{*}{ Eos } & $\mathrm{G} / \mathrm{l}$ & $0.04 \pm 0.05$ & $0.05 \pm 0.09$ & $0.01 \pm 0.03$ & $0.04 \pm 0.04$ & $0.06 \pm 0.01$ \\
\hline & & $\%$ & $0.4 \pm 0.5$ & $0.3 \pm 0.6$ & $0.1 \pm 0.3$ & $0.5 \pm 0.5$ & $0.8 \pm 0.3$ \\
\hline & \multirow[t]{2}{*}{ Bas } & $\mathrm{G} / \mathrm{l}$ & $0.00 \pm 0.00$ & $0.00 \pm 0.00$ & $0.00 \pm 0.00$ & $0.00 \pm 0.00$ & $0.00 \pm 0.00$ \\
\hline & & $\%$ & $0.0 \pm 0.0$ & $0.0 \pm 0.0$ & $0.0 \pm 0.0$ & $0.0 \pm 0.0$ & $0.0 \pm 0.0$ \\
\hline \multirow{10}{*}{2} & \multirow[t]{2}{*}{ Ly } & $\mathrm{G} / \mathrm{l}$ & $0.27 \pm 0.16$ & $0.09 \pm 0.05$ & $0.07 \pm 0.05$ & $0.58 \pm 0.35$ & $11.77 \pm 3.40$ \\
\hline & & $\%$ & $30.8 \pm 8.5$ & $16.7 \pm 5.0$ & $22.0 \pm 17.1$ & $45.0 \pm 26.9$ & $81.3 \pm 6.2$ \\
\hline & \multirow[t]{2}{*}{ Mo } & $\mathrm{G} / \mathrm{l}$ & $0.10 \pm 0.04$ & $0.05 \pm 0.03$ & $0.03 \pm 0.04$ & $0.08 \pm 0.00$ & $0.19 \pm 0.17$ \\
\hline & & $\%$ & $12.3 \pm 5.8$ & $11.3 \pm 9.5$ & $12.0 \pm 14.4$ & $6.0 \pm 0.0$ & $1.2 \pm 0.8$ \\
\hline & \multirow[t]{2}{*}{$\mathrm{Neu}$} & $\mathrm{G} / \mathrm{l}$ & $0.52 \pm 0.25$ & $0.39 \pm 0.17$ & $0.23 \pm 0.14$ & $0.46 \pm 0.60$ & $2.38 \pm 1.05$ \\
\hline & & $\%$ & $57.0 \pm 11.3$ & $72.0 \pm 5.3$ & $66.0 \pm 31.0$ & $35.0 \pm 46.7$ & $16.5 \pm 7.2$ \\
\hline & \multirow[t]{2}{*}{ Eos } & $\mathrm{G} / \mathrm{l}$ & $0.00 \pm 0.00$ & $0.00 \pm 0.00$ & $0.00 \pm 0.00$ & $0.09 \pm 0.13$ & $0.13 \pm 0.09$ \\
\hline & & $\%$ & $0.0 \pm 0.0$ & $0.0 \pm 0.0$ & $0.0 \pm 0.0$ & $7.0 \pm 9.9$ & $1.0 \pm 0.9$ \\
\hline & \multirow[t]{2}{*}{ Bas } & $\mathrm{G} / \mathrm{l}$ & $0.00 \pm 0.00$ & $0.00 \pm 0.00$ & $0.00 \pm 0.00$ & $0.09 \pm 0.13$ & $0.00 \pm 0.00$ \\
\hline & & $\%$ & $0.0 \pm 0.0$ & $0.0 \pm 0.0$ & $0.0 \pm 0.0$ & $7.0 \pm 9.9$ & $0.0 \pm 0.0$ \\
\hline \multirow{10}{*}{8} & \multirow[t]{2}{*}{ Ly } & $\mathrm{G} / \mathrm{l}$ & $2.44 \pm 0.66$ & $0.80 \pm 0.04$ & $0.64 \pm 0.00$ & $\#$ & $9.11 \pm 1.81$ \\
\hline & & $\%$ & $38.3 \pm 6.4$ & $14.0 \pm 1.0$ & $20.0 \pm 0$ & \# & $69.2 \pm 1.6$ \\
\hline & \multirow[t]{2}{*}{ Mo } & $\mathrm{G} / \mathrm{l}$ & $1.32 \pm 0.78$ & $0.76 \pm 0.34$ & $0.51 \pm 0$ & \# & $0.30 \pm 0.18$ \\
\hline & & $\%$ & $19.0 \pm 2.8$ & $13.3 \pm 6.1$ & $16.0 \pm 0$ & $\#$ & $2.2 \pm 1.0$ \\
\hline & \multirow[t]{2}{*}{ Neu } & $\mathrm{G} / 1$ & $2.73 \pm 1.53$ & $4.08 \pm 0.44$ & $2.02 \pm 0$ & \# & $3.59 \pm 0.44$ \\
\hline & & $\%$ & $39.7 \pm 4.6$ & $71.2 \pm 6.8$ & $63.0 \pm 0$ & \# & $27.5 \pm 2.2$ \\
\hline & \multirow[t]{2}{*}{ Eos } & $\mathrm{G} / \mathrm{l}$ & $0.22 \pm 0.21$ & $0.09 \pm 0.08$ & $0.03 \pm 0$ & \# & $0.15 \pm 0.08$ \\
\hline & & $\%$ & $3.0 \pm 2.6$ & $1.5 \pm 1.3$ & $1.0 \pm 0$ & $\#$ & $1.2 \pm 0.8$ \\
\hline & \multirow[t]{2}{*}{ Bas } & $\mathrm{G} / \mathrm{l}$ & $0.00 \pm 0.00$ & $0.00 \pm 0.00$ & $0.00 \pm 0.00$ & $\#$ & $0.00 \pm 0.00$ \\
\hline & & $\%$ & $0.0 \pm 0.0$ & $0.0 \pm 0.0$ & $0.0 \pm 0.0$ & \# & $0.0 \pm 0.0$ \\
\hline \multirow{10}{*}{22} & \multirow[t]{2}{*}{ Ly } & $\mathrm{G} / \mathrm{l}$ & $3.18 \pm 1.11$ & $3.09 \pm 0.72$ & $5.27 \pm 0.00$ & \# & $10.05 \pm 1.99$ \\
\hline & & $\%$ & $56.3 \pm 3.4$ & $47.8 \pm 11.8$ & $65.0 \pm 0$ & \# & $77.0 \pm 2.6$ \\
\hline & \multirow[t]{2}{*}{ Mo } & $\mathrm{G} / 1$ & $1.26 \pm 0.93$ & $1.71 \pm 1.08$ & $0.73 \pm 0$ & \# & $0.22 \pm 0.10$ \\
\hline & & $\%$ & $20.3 \pm 6.3$ & $24.0 \pm 10.0$ & $9.0 \pm 0$ & \# & $1.7 \pm 0.6$ \\
\hline & Neu & $\mathrm{G} / \mathrm{l}$ & $1.19 \pm 0.30$ & $1.79 \pm 0.72$ & $1.94 \pm 0$ & \# & $2.48 \pm 0.20$ \\
\hline & & $\%$ & $21.5 \pm 3.1$ & $26.3 \pm 1.3$ & $24.0 \pm 0$ & \# & $19.3 \pm 2.6$ \\
\hline & Eos & $\mathrm{G} / 1$ & $0.72 \pm 1.11$ & $0.12 \pm 0.11$ & $0.16 \pm 0$ & \# & $0.26 \pm 0.05$ \\
\hline & & $\%$ & $1.8 \pm 0.8$ & $1.5 \pm 0.9$ & $2.0 \pm 0$ & $\#$ & $2.0 \pm 0.5$ \\
\hline & Bas & $\mathrm{G} / 1$ & $0.00 \pm 0.00$ & $0.03 \pm 0.03$ & $0.00 \pm 0.00$ & \# & $0.00 \pm 0.00$ \\
\hline & & $\%$ & $0.0 \pm 0.0$ & $0.3 \pm 0.3$ & $0.0 \pm 0.0$ & $\#$ & $0.0 \pm 0.0$ \\
\hline
\end{tabular}

\# Value was not assessed

\section{Immunophenotyping of leukocytes}

We examined the dynamics of $\mathrm{CD}^{+}$cells (T lymphocytes) and their subpopulations $\mathrm{CD}^{+} 4^{+}$and $\mathrm{CD}^{+} 8^{+}$cells, as well as changes of $\mathrm{CD} 3-8^{+}$and $\mathrm{CD} 34^{+}$cells. There was a clear dose-dependent drop of $\mathrm{CD}^{+}$cells at the dose of $30 \mathrm{mg} / \mathrm{kg}$. Also, higher susceptibility of $\mathrm{CD}^{+}\left(\mathrm{CD}^{+}\right.$and $\left.\mathrm{CD}^{-}\right)$cells than $\mathrm{CD}^{+}$cells to chlorambucil was noticed but nonsignificant (Table 3). 
Table 3. Immunophenotyping of leukocytes (\%). Stage 3

\begin{tabular}{|l|c|c|r|r|r|r|r|r|r|r|}
\hline \multirow{2}{*}{$\begin{array}{c}\text { Chlorambucil dose } \\
\mathrm{mg} / \mathrm{kg} / \text { day }\end{array}$} & \multicolumn{9}{|c|}{ Initial values } & \multicolumn{5}{c|}{3 days after the end of therapy } \\
\cline { 2 - 12 } & $\mathrm{CD}^{+}$ & $\mathrm{CD}^{+} 4^{+}$ & $\mathrm{CD}^{+} 8^{+}$ & $\mathrm{CD} 34^{+}$ & $\mathrm{CD} 3-8^{+}$ & $\mathrm{CD}^{+}$ & $\mathrm{CD}^{+} 4^{+}$ & $\mathrm{CD}^{+} 8^{+}$ & $\mathrm{CD} 34^{+}$ & $\mathrm{CD} 3-8^{+}$ \\
\hline 20 & 38.67 & 28.02 & 11.38 & 24.80 & 20.57 & 35.52 & 21.02 & 26.02 & $11.53^{*}$ & 37.13 \\
& \pm 3.61 & \pm 3.08 & \pm 2.29 & \pm 5.47 & \pm 8.59 & \pm 13.77 & \pm 11.57 & \pm 20.83 & \pm 7.43 & \pm 17.40 \\
\hline 30 & 40.95 & 30.02 & 10.38 & 23.05 & 15.35 & $10.45^{* *}$ & $5.00^{* *}$ & 12.55 & 9.80 & 57.85 \\
& \pm 4.33 & \pm 2.95 & \pm 1.21 & \pm 5.34 & \pm 5.52 & \pm 5.25 & \pm 2.71 & \pm 16.69 & \pm 14.65 & \pm 37.79 \\
\hline 40 & 38.80 & 27.27 & 12.35 & 24.68 & 12.63 & 11.75 & 8.65 & 4.35 & 23.20 & $76.55^{*}$ \\
& \pm 5.90 & \pm 5.94 & \pm 2.21 & \pm 6.69 & \pm 9.28 & \pm 6.72 & \pm 4.45 & \pm 1.20 & \pm 27.29 & \pm 3.04 \\
\hline 50 & 40.98 & 29.60 & 11.38 & 24.82 & 20.40 & $\#$ & $\#$ & $\#$ & $\#$ & $\#$ \\
& \pm 8.48 & \pm 5.40 & \pm 3.36 & \pm 8.21 & \pm 4.37 & & & & & \\
\hline Control & 49.23 & 34.97 & 14.2 & 30.5 & 22.7 & 45.10 & 33.30 & 12.23 & 24.20 & 19.10 \\
& \pm 7.42 & \pm 4.50 & \pm 2.33 & \pm 2.00 & \pm 3.55 & \pm 5.07 & \pm 2.81 & \pm 2.39 & \pm 3.86 & \pm 2.07 \\
\hline
\end{tabular}

\# Value was not assessed

* Significant change $(p<0.05)$

$* *$ Highly significant change $(p<0.01)$

Biochemical indicators

Almost no changes were found in the concentrations of ions. Likewise, urea and creatinine showed only minimal changes in all groups. Activity of alkaline phosphatase varied with the dose. At the lowest concentrations it was mildly lowered (stage 1), mildly increased in stage 2 , and decreased in stage 3 due to the cessation of growth. ALT activity decreased in dependence on the dose, except for the group with $50 \mathrm{mg} / \mathrm{kg} / \mathrm{day}$, in which a considerable rise was found. AST activity decreased in groups receiving higher doses. All changes were non-significant $(p>0.05)$ in experimental as well as control animals.

Histological examination

Samples of individual organs were collected from animals receiving the highest dose (stage 3). Histological examination revealed pneumotoxicity (haemorrhage within bronchi, damage to the structure of bronchial epithelium, locally nearly bullous emphysema with areas of parenchyma carnification) and nephrotoxicity, severity of which was chlorambucil dose-dependent. There was damage to the epithelium of proximal and distal renal tubules at all doses and cortical haemorrhage in animals with the highest dose $(50 \mathrm{mg} / \mathrm{kg} / \mathrm{day})$. GIT toxicity manifested itself by defects of the epithelium leading to uncovering the fibrous stroma of villi in the duodenum, jejunum, ileum, caecum and colon descendens; gastric and esophageal mucosa remained intact. Other organs examined showed no histopathological changes. Organs of the control animals did not show the previously described changes.

\section{Discussion}

Low-dose chlorambucil is a relatively safe and low-toxic drug. Marked side effects are described during a high-dose therapy or accidental intoxication. The main side effects recognised in human medicine include myelosuppression - pancytopenia, anaemia, thrombocytopaenia and/or leukopaenia (Nicolle et al. 2004; Summerfield et al. 2002; Blumenreich et al. 1988), neurotoxicity - changes of EEG, fits, seizures, apathy, derangement, ataxia, excitability (Hehn et al. 2003; Byrne et al. 1981; Pradhan and Marsan 1963), gastrointestinal toxicity (vomiting, nausea, diarrhoea), fertility disorders and increased risk of secondary malignancies (Summerfield et al. 2002). Hepatotoxicity and pneumotoxicity have been reported only infrequently (Summerfield et al. 2002; Blumenreich et al. 1988).

Low doses of chlorambucil $(0.15-0.75 \mathrm{mg} / \mathrm{kg} /$ day $)$ were well tolerated and the rats showed no clinical and laboratory changes. Intermediate doses $(2-12 \mathrm{mg} / \mathrm{kg} / \mathrm{day})$ were 
also tolerated very well with only mild changes of white blood cells and mild increment in activities of liver enzymes; these doses did not result in significant clinical changes of the physiological state of health.

Acute toxicity of chlorambucil was only found in groups of experimental animals receiving the highest doses (20-50 mg/kg/day); there were deaths of several individuals and a body weight decrease. The most severe damage to organs during stage 3 of the experiment was found in the bone marrow, kidneys, lungs and intestines. Myelotoxicity resulted mostly in leukopaenia. There was a profound drop in leukocytes lower than $1 \times 10^{9} / 1$ during the first week of administrations. The drop was only of short duration because the numbers of blood cells were beginning to return to the reference interval during the second week of the experiment; however, two months were not sufficient enough for the counts to return to the initial values. At the same time there was a change in the percentage of leukocyte types. Lymphocytes dropped from the initial $70 \%$ to $5 \%$ and granulocytes and monocytes increased. The change in the ratio of $\mathrm{CD}^{+}$and $\mathrm{CD}^{+}$lymphocytes in favour of $\mathrm{CD}^{+}$ demonstrates higher resistance of $\mathrm{CD}^{+}$lymphocytes to cytotoxic effects of chlorambucil. Contrary to the reported cases of myelosuppression in humans (Summerfield et al. 2002), we did not notice changes in the red blood cell and platelet counts. Changes of white blood cells (leukopaenia with fast recovery after cessation of the therapy) were similar as described in humans (Summerfield et al. 2002; Blumenreich et al. 1988).

Nephrotoxicity was revealed only after histological examination (dose-dependent damage to the epithelium of proximal and distal renal tubules, cortical haemorrhage in animals with the highest dose) because plasma biochemical indicators such as urea and creatinine as well as potassium, sodium and chlorides were not altered. Nephrotoxicity has been reported as a side effect to the therapy by chlorambucil infrequently; although a case of acute renal failure (acute tubular necrosis) has been recognised following overdose (Blank et al. 1983).

Profound toxic effects were found in the lung parenchyma (haemorrhage within bronchi, damage to the structure of bronchial epithelium, local nearly bullous emphysema with areas of parenchyma carnification). Pneumotoxicity has rarely been described in humans; most commonly the administration of chlorambucil results in interstitial pneumonia, fibrosis, and damage to the alveolar epithelium, or pneumonia due to the obliteration of bronchi (Weiss et al. 1980; Kalambokis et al. 2004; Khong 1988). Most frequent signs of gastrointestinal tract damage include vomiting, diarrhoea, anorexia, stomatitis, etc. Gastrointestinal toxicity of chlorambucil in our experimental rats resulted in damage to the small and large intestinal epithelium, in particular, without severe clinical manifestations (only anorexia and mild diarrhoea). There was no damage to the esophageal and gastric epithelium.

Although relatively frequently reported, there were no signs of neurotoxicity in animals in our study. The only sign showing damage to the nervous system was that of apathy. Neurotoxicity in humans as well as laboratory animals may frequently manifest only as changes of EEG (Pradhan and Marsan 1963). Other signs include apathy or, on the other hand, hyperexcitability, ataxia, and derangement or alteration of mood (Hehn et al. 2003). These effects may occur at standard dosage (10-12 $\mathrm{mg} / \mathrm{m}^{2}$ of body surface). Some patients, such as elderly humans, children suffering from the nephrotic syndrome, and overdosed ones, may show epileptiform seizures and clonic convulsions (Byrne et al. 1981; Salloum et al. 1997).

In conclusion, toxicity of chlorambucil was evident only after the administration of high doses. Doses of 50 and $40 \mathrm{mg} / \mathrm{kg} /$ day showed acute lethal effects. The main toxicity recognised was that of haematological manifestation (leukopaenia), nephrotoxicity (damage to the tubular epithelium), pneumotoxicity (emphysema, carnification of parenchyma, damage of bronchial epithelium) and gastrointestinal damage (defects of intestinal epithelium). 
These data are intended for use in the testing of combinations of chlorambucil with other chemoterapeutics when preparing the non-myeloablative regimen for the bone marrow transplantation. Doses used in stage 2 of experiment $(2-12 \mathrm{mg} / \mathrm{kg} /$ day $)$ seem to be useful for further tests. Their non-haematological toxicity was acceptable and a mild myelosuppressive effect, crucial for transplantation of haematopoietic cells, was found. This effect will be probably deepened if chlorambucil is combined with other myeloablative and/or immunosuppressive drugs.

\section{Toxicita vysokých dávek chlorambucilu u potkanů kmene Wistar}

Cílem studie bylo stanovit maximální tolerovanou dávku a hematologickou a nehematologickou toxicitu chlorambucilu u potkanů (samců) kmene Wistar. Chlorambucil (rozdrcené tablety nebo čistá substance) byl rozpuštěn $\mathrm{v}$ etanolu a podáván perorálně v dávkách $0,15-50 \mathrm{mg} / \mathrm{kg} / \mathrm{den} 5$ dnů.

Sledován byl celkový klinický stav zvírat, hmotnost, hematologické ukazatele (celkový počet erytrocytů, leukocytů, trombocytů, diferenciální rozpočet leukocytů, hematokrit a koncentrace hemoglobinu), biochemické ukazatele plazmy (urea, kreatinin, ALP, ALT, AST, Na, K, Cl), imunofenotyp leukocytů (znaky CD3, CD8 a CD4), rovněž bylo provedeno histologické vyšetření tkání. Dávky chlorambucilu 0,15 až $0,75 \mathrm{mg} / \mathrm{kg} / \mathrm{den}$ neovlivnily klinický stav zvírat ani laboratorní ukazatele. Dávky $2-12 \mathrm{mg} / \mathrm{kg} / \mathrm{den}$ byly tolerovány rovněž velmi dobře, objevila se mírná myelotoxicita (leukopenie) a elevace jaterních transamináz. Dávky $20-50 \mathrm{mg} / \mathrm{kg} / \mathrm{den}$ měly účinek myelotoxický - leukopenie $(p<0,01)$ s dominantní lymfopenií, ovlivnění erytrocytů a trombocytů bylo minimální, histologické vyšetření odhalilo pneumotoxicitu a nefrotoxicitu a gastrointestinální toxicitu. Dávky 40 a $50 \mathrm{mg} / \mathrm{kg} / \mathrm{den}$ měly akutní letální účinek u $50 \%$ resp. $75 \%$ jedinců.

Výsledky studie budou využity pro testování kombinací chlorambucilu s dalšími léky jako prrípravného režimu pro transplantace kostní dřeně.

\section{Acknowledgement}

This work was supported by grant No.18/2006/FVL.

\section{References}

BLANK DW, NANJI AA, SCHREIBER DH, HUDMAN C, SANDERS HD 1983: Acute renal failure and seizures associated with chlorambucil overdose. J Toxicol Clin Toxicol 20: 361-365

BLUMENREICH MS, WOODCOCK TM, SHERRILL EJ, RICHMAN SP, GENTILE PS, EPREMIAN BE, KUBOTA TT, ALLEGRA JC 1988: A phase I trial of chlorambucil administered in short pulses in patients with advanced malignancies. Cancer Invest 6: 371-375

BOYCE KL, KITCHELL BE 2000: Treatment of canine lymphoma with COPLA/LVP. J Am Anim Hosp Assoc 36: $395-403$

BYRNE TN, MOSELEY TAE, FINER MA 1981: Myoclonic seizures following chlorambucil overdose. Ann Neurol 9: 191-194

CALABRESI P, CLARK J, HANAUSKE AR, WIEMANN MC 1993: Pharmacology of antineoplastic agents. In: CALABRESI P, SCHEIN PS (Eds): Medical oncology. $2^{\text {nd }}$ ed. McGraw-Hill, New York, pp. 263-322

HEHN ST, DORR RT, MILLER TP 2003: Mood alterations in patients treated with chlorambucil. Clin Lymphoma 4: $179-182$

KALAMBOKIS G, STEFANOU D, ARKOUMANI E, TSIANOS E 2004: Bronchiolitis obliterans organizing pneumonia following chlorambucil treatment for chronic lymphocytic leukemia. Eur J Haematol 73: 139-142

KHONG HT, McCARTHY J 1998: Chlorambucil-induced pulmonary disease: a case report and review of the literature. Ann Hematol 77: 85-87

KISELOW MA, RASSNICK KM, McDONOUGH SP, GOLDSTEIN RE, SIMPSON KW, WEINKLE TK, ERB HN 2008: Outcome of cats with low-grade lymphocytic lymphoma: 41 cases (1995 - 2005). J Am Vet Med Assoc 232: 405-410

NICOLLE A, PROCTOR SJ, SUMMERFIELD GP 2004: High dose chlorambucil in the treatment of lymphoid malignancies. Leuk Lymphoma 45: 271-275

PANGALIS GA, VASSILAKOPOULOS TP, DIMOPOULOU MN, SIAKANTARIS MP, KONTOPIDOU FN, ANGELOPOULOU MK 2002: B-chronic lymphocytic leukemia: practical aspects. Hematol Oncol 20: 103-146 
PRADHAN SN, MARSAN CA 1963: Chlorambucil toxicity and EEG “centrencephalic" patterns. Epilepsia 4: $1-14$

SALLOUM E, KHAN KK, COOPER DL 1997: Chlorambucil-induced seizures. Cancer 79: 1009-1013

SUMMERFIELD GP, TAYLOR PRA, MOUNTER PJ, PROCTOR SJ 2002: High-dose chlorambucil for the treatment of chronic lymphocytic leukaemia and low-grade non-Hodgkin's lymphoma. Br J Haematol 116: 781-786

WEISS RB, MUGGIA FM 1980: Cytotoxic drug-induced pulmonary disease. Am J Med 68: 259-266 